\title{
FUNGSI HAK ANGKET DEWAN PERWAKILAN RAKYAT UNTUK MELAKUKAN PENYELIDIKAN TERHADAP PELAKSANAAN UNDANG-UNDANG
}

\author{
Siti Sumartini, \\ Jajang Arifin \\ Universitas Wiralodra \\ Email : sitisumartini_unwir@yahooo.co.id, \\ jajangarifincyber@gmail.com
}

\begin{abstract}
The inquiry right of the House of Representatives (DPR-Dewan Perwakilan Rakyat) is the right of the DPR to conduct an investigation of the implementation of laws/government policies relating to important things, strategic, and broad impacts on the life of the community, nation, and state suspected of being in conflict with the law regulations. The $D P R$ 's inquiry rights relating to the implementation of the DPR's oversight function are "an institutionalized system, involving the effectiveness and regularity of restrictions on government actions". According to the definition above, the questions arise is what is the position of the inquiry rights in the implementation of the DPR's oversight function on the implementation of a law? What is the implication of the Constitutional Court's decision Number: 36 / PUU-XV / 2017 for the implementation of the DPR's inquiry right to the Corruption Eradication Commission (KPK - Komisi Pemberantasan Korupsi)? The study was conducted using a normative juridical approach (legal research). In this case, testing and reviewing secondary data are done relating to the problem to be discussed. The inquiry right is not the right to know about the possibility of a crime in a case. The inaccuracy in the conception of the inquiry right which is also shown in its implementation such as the DPR investigating the Bullogate, BLBI cases and others can (even) distort the function of the DPR in the formation of laws (legislation) or oversight of the implementation of government tasks and state spending, including the appointment of public officials in the form of public officials, approval or rejection, or in the form of giving consideration by the Parliament. Therefore, if the function is expected to be carried out effectively, dynamically, and naturally, changes to the MD3 Law must be initiated primarily by members of the DPR itself. There must be a strong desire from the members of Parliament to reposition themselves as representatives of the people who are aspirational and serve the interests of all the people they represent. This strong desire will manifestly manifest, if they are not restarted, because they are opposing the party's policy line.
\end{abstract}

Keywords: Inquiry Rights, House of Representatives' Oversight Function, Investigation of Laws

\section{PENDAHULUAN}

Hak Angket Dewan Perwakilan Rakyat (DPR) adalah hak DPR untuk melakukan penyelidikan terhadap pelaksanaan suatu undang-undang/kebijakan pemerintah yang berkaitan dengan hal penting, strategis, dan berdampak luas pada kehidupan bermasyarakat, berbangsa, dan bernegara yang diduga bertentangan dengan peraturan 
perundang-undangan. Hak angket DPR yang terkait dengan pelaksanaan fungsi pengawasan DPR, adalah "suatu sistem yang terlembagakan, menyangkut pembatasan yang efektif dan teratur terhadap tindakan-tindakan pemerintahan"1 dan pelaksanaan Hak DPR selain hak angket, yakni: Hak Interpelasi, hak interpelasi adalah hak DPR untuk meminta keterangan kepada Pemerintah mengenai kebijakan pemerintah yang penting dan strategis serta berdampak luas pada kehidupan bermasyarakat, berbangsa, dan bernegara, dan Hak Menyatakan Pendapat adalah hak DPR untuk menyatakan pendapat atas:

a. kebijakan pemerintah atau mengenai kejadian luar biasa yang terjadi di tanah air atau di dunia internasional;

b. tindak lanjut pelaksanaan hak interpelasi dan hak angket; atau

c. dugaan bahwa Presiden dan/atau Wakil Presiden melakukan pelanggaran hukum baik berupa pengkhianatan terhadap negara, korupsi, penyuapan, tindak pidana berat lainnya, maupun perbuatan tercela, dan/atau Presiden dan/atau Wakil Presiden tidak lagi memenuhi syarat sebagai Presiden dan/atau Wakil Presiden.

Selajutnya dalam melaksanakan fungsinya Dewan Perwakilan Rakyat mempunyai hak salah satunya adalah hak angket yang erat hubungannya dengan Hak Dewan Perwakilan Rakyat sebagai anggota dan kelembagaan, merujuk kepada pandangan Bagir manan memaparkan sebagai berikut: "Hak angket lazim disandingkan dengan hak penyelidikan, pemakaian istilah hak penyelidikan dapat menimbulkan salah pengertian dikarenakan istilah penyelidikan merupakan proses awal dalam mengungkapkan dugaan telah terjadi perbuatan pidana, sebagaimana terjemahan opsporing (Belanda). Meskipun hak angket berasal dari bahasa asing (Prancis: anguete) tetapi telah diterima sebgai istilah ketatanegaraan dalam bahasa Indonesia ${ }^{2} . "$

Penggunaan Hak Angket DPR menjadi polemik perdebatan konstitusional adalah menyangkut DPR yang menggunakan hak angket terhadap pelaksanaan UU Komisi Pemberantasan Korupsi (KPK) diawali dengan DPR melalui rapat paripurna secara resmi mengesahkan pembentukan Panitia Khusus Hak Angket Komisi Pemberantasan Korupsi (Pansus Hak Angket KPK) pada 30 Mei 2017. Pansus Hak Angket KPK tetap dibentuk meskipun ada banyak penolakan baik dari masyarakat maupun dari beberapa fraksi di DPR

\footnotetext{
1 Jimly Asshiddiqie, Menuju Negara Hukum Yang demokrasi, PT Bhuana Ilmu Populer, Jakarta, 2009, hlm. 50-53.

2 Sri Soemantri, Tentang Lembaga-lembaga Negara Menurut UUD 1945, Cet VII, PT Citra Aditya Bakti, 1993, hlm. 63 .
} 
itu sendiri. Selama masa kerja 60 hari, Pansus Hak Angket akan bekerja menggali keterangan mengenai fungsi pemberantasan korupsi yang dilakukan KPK.

Meskipun sudah disahkan, keberadaan Pansus Hak Angket KPK menuai banyak kritik dari berbagai kalangan masyarakat. Kecurigaan akan adanya konflik kepentingan (conflict of interest) pun mengemuka, karena latar belakang usulan Hak Angket tersebut adalah mendesak KPK agar membuka rekaman pemeriksaan Miryam Haryani, anggota DPR yang menjadi tersangka karena telah memberikan keterangan palsu dalam kasus korupsi E-KTP.

Hak Angket sendiri diatur dalam pasal 79 ayat (3) Undang-undang No.17 tahun 2014 yang menyebutkan bahwa Hak Angket merupakan hak DPR untuk melakukan penyelidikan terhadap pelaksanaan undang-undang dan/atau kebijakan pemerintah yang berkaitan dengan hal penting, strategis, dan berdampak luas pada kehidupan bermasyarakat, berbangsa, bernegara yang diduga bertentangan dengan peraturan perundang-undangan.

Berdasarkan pasal tersebut, Hak Angket yang bisa dilakukan DPR terbatas pada penyidikan terhadap undang-undang atau kebijakan pemerintah yang bersifat penting, strategis, berdampak luas dan bertentangan dengan peraturan perundang-undangan. Jika mengacu kepada pasal tersebut, maka sebenarnya DPR tidak dapat mengajukan Hak Angket terhadap KPK, sebab KPK sebagai lembaga negara sama sekali tidak melakukan pelanggaran hukum yang penting, strategis dan berdampak luas dalam melaksanakan tugas dan kewajibannya.

Pembentukan Pansus Hak Angket KPK tersebut pun berujung pada konflik antara DPR dan KPK. Pada satu sisi, DPR bersikukuh bahwa pembentukan pansus merupakan kewenangannya sebagai lembaga legislatif dan sesuai dengan aturan yang ada. Namun di sisi lain, citra DPR yang dianggap buruk di mata masyarakat menimbulkan spekulasi yang mengarah pada 'opini' bahwa DPR sedang berupaya melemahkan KPK. Selain itu manuver politik yang sedang dilakukan DPR dengan menggulirkan Hak Angket kepada KPK juga dapat dicurigai sebagai upaya untuk menghambat pemeriksaan dan penyidikan kasus E-KTP.

Perdebatan konstitusiaonal tersebut pada akhirnya bermuara dilakukannya pengujian UU MD3 terhadap UUD 1945 di MK dalam perkara Nomor: 36/PUU-XV/2017. Isu penting dalam perdebatan konstitusional nya adalah, apakah DPR berwenang 
melakukan hak angket terhadap KPK yang memiliki fungsi penyelidikan, penyidikan dan penuntutan. Isu tersebut lah yang akan peneliti tuangkan dalam penulisan penelitian ini dan akan memberikan judul: "Fungsi hak angket DPR untuk melakukan penyelidikan terhadap pelaksanaan suatu undang-undang dihubungkan dengan Putusan Mahkamah Konstutusi Nomor: 36/PUU-XV/2017.

Berdasarkan permasalah yuridis tersebut di atas, peneliti akan memberikan batasan masalah terdapat beberapa permasalahan yakni:

1. Bagaimanakah kedudukan Hak Angket dalam pelaksanaan Fungsi pengawasan DPR terhadap pelaksanaan suatu undang-undang?

2. Bagaimanakah implikasi putusan MK Nomor: 36/PUU-XV/2017 terhadap pelaksanaan hak angket DPR terhadap KPK?

\section{METODE}

Spesifikasi penelitian ini adalah yuridis analisis yaitu metode yang menggambarkan atau memaparkan suatu fakta atau kenyataan secara sistematis ${ }^{3}$. Oleh karena penelitian ini adalah penelitian dalam bidang ilmu hukum maka spesifikasi penelitian deskriptif analisisnya, adalah: "Berusaha menggambarkan masalah hukum, sistem hukum dan menganalisisnya sesuai dengan kebutuhan dari peneliti yang bersangkutan."

Kajian dilakukan dengan pendekatan yuridis normative (legal research $)^{4}$. Dalam hal ini menguji dan mengkaji data sekunder yang berkaitan dengan permasalahan yang akan dibahas.

Sesuai dengan tipe penelitian yaitu penelitian hukum yuridis normatif maka data yang diperoleh pada dasarnya melalui penelitian kepustakaan (library research). Penelitian kepustakaan dilakukan dengan cara mengumpulkan dan mempelajari bahan hukum primer, bahan hukum sekunder, dan bahan hukum tertier, yaitu :

a. Bahan hukum primer yaitu, meliputi peraturan perundang-undangan yang terkait dengan pelaksanaan hak angket.

b. Bahan hukum sekunder, yaitu bahan hukum yang memberikan kejelasan mengenai bahan hukum primer yang meliputi buku-buku yang ditulis oleh pakar hukum, surat kabar, majalah dan artikel yang memiliki keterkaitan yang erat dengan masalah yang akan dibahas.

\footnotetext{
3 Soerjono Soekanto, Pengantar Penelitian Hukum-Cet Ke-3, Jakarta: UI Press, 1984, hlm. 10.

4 Ibid.
} 
c. Bahan hukum tertier, yaitu bahan yang memberikan petunjuk maupun penjelasan terhadap bahan hukum primer dan sekunder, berupa kamus, ensiklopedia, bibliografi, indeks dan sebagainya yang ada kaitannya dengan pembahasan dalam penelitian ini.

Selain teknik studi kepustakaan penelitian juga melakukan wawancara dengan nara sumber dari kalangan akademisi dan praktisi yang berkompeten di bidang ketatanegaraan. Hal ini dilakukan guna memperoleh data dan informasi untuk melengkapi data studi kepustakaan.

Pengumpulan data dilakukan dengan cara melakukan studi dokumen, yaitu menganalisa bahan pustaka. Semua bahan-bahan dan informasi yang telah dikumpulkan dianalisis secara yuridis kualitatif, guna menarik kesimpulan atas pokok permasalahan yang diajukan. Selanjutnya hasil analisis yuridis kualitatif tersebut akan dipaparkan secara deskriptif, tanpa menggunakan prosedur pengolahan data statistik.

\section{HASIL DAN PEMBAHASAN}

\subsection{Kedudukan Hak Angket Dewan Perwakilan Rakyat Dalam Sistem Ketatanegaraan Republik Indonesia}

Berdasarkan tata urutan pada Pasal 7 ayat (1) Undang-Undang Republik Indonesia Nomor 12 Tahun 2011 tentang Pembentukan Peraturan Perundang-Undangan. Maka sebagai acuan dasar hukum penerapan hak angket pada konstitusi. Hak angket bermula dari perkembangan konstitusi atau hukum dasar dari Republik Indonesia. Hak angket awal dikenal pada Pasal 121 dalam penerapan konstitusi Republik Indonesia Serikat, kemudian negara Indonesia merubah konstitusi yaitu konstitusi Federal, maka hak angket diatur kembali pada Pasal 70 Undang-Undang Dasar Sementara Nomor 7 Tahun 1950 (LN 195056, d.u. 15 Ag 1950). Dalam Pasal 20A ayat (2) Undang-Undang Dasar Negara Republik Indonesia Tahun 1945 hak angket diatur kembali, namun tidak mendefiniskan pengertian hak angket tersebut. Maka hak angket diatur secara khusus lagi dalam undang-undang yaitu:

a. Undang-Undang Republik Indonesia Nomor 6 Tahun 1954 tentang Penetapan Hak Angket Dewan Perwakilan Rakyat (Lembaran Negara Republik Indonesia Tahun 1954 Nomor 19; Tambahan Lembaran Negara Nomor 518);

b. Undang-Undang Republik Indonesia Nomor 22 Tahun 2003 tentang Susunan Dan Kedudukan Majelis Permusyawaratan Rakyat, Dewan Perwakilan Rakyat, Dewan 
Perwakilan Daerah, Dan Dewan Perwakilan Rakyat Daerah (Lembaran Negara Republik Indonesia Tahun 2003 Nomor 92);

c. Undang-Undang Republik Indonesia Nomor 27 Tahun 2009 tentang Majelis Permusyawaratan Rakyat, Dewan Perwakilan Rakyat, Dewan Perwakilan Daerah, Dan Dewan Perwakilan Rakyat Daerah (Lembaran Negara Republik Indonesia Tahun 2009 Nomor 123; Tambahan Lembaran Negara Republik Indonesia Nomor 5043);

d. Undang-Undang Republik Indonesia Nomor 42 Tahun 2014 tentang perubahan atas Undang-Undang Republik Indonesia Nomor 17 Tahun 2014 tentang Majelis Permusyawaratan Rakyat, Dewan Perwakilan Rakyat, Dewan Perwakilan Daerah, Dan Dewan Perwakilan Rakyat Daerah (Lembaran Negara Republik Indonesia Tahun 2014 Nomor 383; Tambahan Lembaran Negara Nomor 5650);

e. Peraturan Dewan Perwakilan Rakyat Republik Indonesia Nomor 1 Tahun 2009 tentang Tata Tertib; dan

f. Peraturan Dewan Perwakilan Rakyat Republik Indonesia Nomor 3 Tahun 2015 tentang Tata Tertib.

Perubahan Undang-Undang Dasar Negara Republik Indonesia Tahun 1945, memberikan kewenangan lebih dominan kepada Dewan Perwakilan Rakyat dengan mengatur kembali hak menyelidiki secara konprehensif pada ketentuan Undang-Undang Dasar Negara Republik Indonesia Tahun 1945 perubahan kedua yang disahkan pada tanggal 18 Agustus 2002 menjadi hak angket, sebagai salah satu upaya untuk menutupi kelemahan yang terdapat dalam Undang-Undang Dasar Negara Republik Indonesia Tahun 1945 serta memperkuat tatanan ketatanegaraan, demi terjamin adanya sistem pengawasan dan keseimbangan diantara lembaga tinggi negara agar memiliki akuntabilitas yang jelas.

Rumusan Pasal 20A Undang-Undang Dasar Negara Republik Indonesia Tahun 1945 terkait hak angket menjadi hak konstitusional atau hak kelembagaan Dewan Perwakilan Rakyat mengingat Dewan Perwakilan Rakyat adalah lembaga negara sebagai representatif dari rakyat, dengan kedaulatan yang berada pada rakyat. Sehingga diputuskan perubahan Undang-Undang Dasar Negara Republik Indonesia Tahun 1945, dengan adanya penambahan Pasal 20A yang mencantumkan hak angket pada dasarnya merupakan hak kelembagaan untuk menjaga eksitensi Dewan Perwakilan Rakyat dalam menjalankan fungsi pengawasan serta mempertegas kedudukan dari Dewan Perwakilan Rakyat agar terciptanya sistem pengawasan dan keseimbangan antara lembaga tinggi negara. 
Mengingat Pasal 7C Undang-Undang Dasar Negara Republik Indonesi Tahun 1945 "Presiden tidak dapat membekukan dan/atau membubarkan Dewan Perwakilan Rakyat". Disisi lain kedudukan Dewan Perwakilan Rakyat yang memiliki kewenangan sebagaimana dijelaskan dalam Pasal 20A Undang-Undang Dasar Negara Republik Indonesia Tahun 1945 tidak mengurangi kewenangan lembaga negara lainnya, termasuk pada eksekutif.10

Kewenangan Dewan Perwakilan Rakyat dalam melaksaanakan hak angket tidak terlepas dari sejarah bangsa Indonesia yang perna menerapakan Konstitusi Republik Indonesia Serikat dan Undang-Undang Dasar Sementara yang mengenal adanya hak angket, sehingga dibuatlah Undang-Undang Republik Indonesia Nomor 6 Tahun 1954 tentang Penetapan Hak Angket Dewan Perwakilan Rakyat (Lembaran Negara Republik Indonesia Tahun 1954 Nomor 19; Tambahan Lembaran Negara Nomor 518) sebagai landasan bagi Dewan Perwakilan Rakyat dalam melaksanaka hak angket. Namun UndangUndang tersebut telah dicabut dengan keputusan Mahkamah Konstitusi Nomor 8/PUUVIII/2010.11 Selanjutnya terkait dengan pelaksanaan hak angket menjadi kewenangan dari Dewan Perwakilan Rakyat diatur pada Pasal 199 ayat (1) Undang-Undang Republik Indonesia Nomor 42 Tahun 2014 tentang perubahan atas Undang-Undang Republik Indonesia Nomor 17 Tahun 2014 tentang Majelis Permusyawaratan Rakyat, Dewan Perwakilan Rakyat, Dewan Perwakilan Daerah, Dan Dewan Perwakilan Rakyat Daerah (Lembaran Negara Republik Indonesia Tahun 2014 Nomor 383; Tambahan Lembaran Negara Nomor 5650) termaktub:

"Hak angket sebagaimana dimaksud dalam pasal 79 ayat (1) huruf b diusulkan paling sedikit 25 (dua puluh lima) orang anggota Dewan Perwakilan Rakyat dan lebih dari 1 (satu) fraksi."

Artinya bahwa hak angket, dapat terlaksana apabila diusulkan oleh Dewan Perwakilan Rakyat, kemudian diajukan kepimpinan Dewan Perwakilan Rakyat selanjutnya disidangkan untuk mendapatkan persetujuan dari anggotata Dewan Perwakilan Rakyat yang lainnya. Dalam mekanisme penerapan hak angket berdasarkan Undang-Undang Republik Indonesia Nomor 42 Tahun 2014 tentang perubahan atas Undang-Undang Republik Indonesia Nomor 17 Tahun 2014 tentang Majelis Permusyawaratan Rakyat, Dewan Perwakilan Rakyat, Dewan Perwakilan Daerah, Dan Dewan Perwakilan Rakyat Daerah (Lembaran Negara Republik Indonesia Tahun 2014 Nomor 383; Tambahan Lembaran Negara Nomor 5650) dan Peraturan Dewan Perwakilan Rakyat Republik Indonesia Nomor 3 Tahun 2015 tentang Tata Tertib. Jika setujui maka dibentuk panitia angket dan diumumkan dalam berita negara. Dalam menjalankan hak angket secara yuridis 
yang menjadi panitia hak angket dengan keanggotaannya terdiri atas semua unsur fraksi Dewan Perwakilan Rakyat. Maka dalam pelaksanaan hak angket secara keseluruhannya merupakan bagian dari pelaksanaan dan menjadi kewenangan yang dilakukan oleh Dewan Perwakilan Rakyat.

Setelah panitia angket menyelesaikan pekerjaannya, maka panitia angket yang terdiri dari setiap fraksi melaporkan kepada pimpinan Dewan Perwakilan Rakyat, selanjutnya dibahas dan mendapatkan tanggapan dari setiap fraksi, untuk mendaptkan keputusan, yang selanjutnya dilaporkan kepada Presiden. Artinya bahwa dalam penerapan hak angket atas kebijakan pemerintah secara untuh merupakan kewenangan dari Dewan Perwakilan Rakyat untuk melaksanakan hak angket hingga pada proses pelaporan atas temuan dari penyelidikan yang dilakukan Dewan Perwakilan Rakyat.

\section{a. Kedudukan Hak Angket Dalam Pelaksanaan Fungsi Pengawasan DPR Terhadap Pelaksanaan Suatu Undang-Undang}

Saat ini Indonesia memasuki era reformasi, dengan sistem ketatanegaraan yang mengalami pergeseran dari sistem ketatanegaraan sebelumnya berdasarkan UndangUndang Dasar Negara Republik Indonesia Tahun 1945. Maka pemisahan kekuasaan eksekutif-legislatif itu makin tegas adanya ${ }^{5}$. Mekanisme hubungan antara negara dan rakyat dalam suatu negara dengan kepentingan negara biasanya diwakili oleh pemerintah, sedangkan kepentingan rakyat diinstitusionalisasikan atau terlembagakan melalui parlemen ${ }^{6}$.

Pemisahan kekuasaan dilakukan dengan harapan terwujudnya sistem pengawasan dan keseimbangan dalam pembagian kekuasaan yang dilakukan sehingga Presiden dalam menjalankan kekuasaannya mendapatkan pengawasan dari Dewan Perwakilan Rakyat sebagai lembaga yang menaungi kepentingan rakyat. Pengawasan dilakukan tidak hanya setelah adanya kegiatan atau kebijakan yang dikeluarkan, tetapi juga sebelum dikeluarkannya kebijakan Dewan Perwakilan Rakyat memiliki kewenangan untuk memberikan masukan salah satunya dijelaskan pada Pasal 13 ayat (2) Undang-Undang Dasar Negara Republik Indonesia Tahun 1945 termaktub:

"Dalam hal mengangkat duta, Presiden memperhatikan pertimbangan Dewan Perwakilan Rakyat"

\footnotetext{
5 Jimly Asshiddiqie, Hukum Tata Negara dan Pilar-Pilar Demokrasi, Sinar Grafika, Jakarta, 2012, hlm. 16.

${ }^{6} \mathrm{Ibid}, \mathrm{hlm} .26$.
} 
Kekuasaan lembaga legislatif yang didalamnya merupakan lembaga perwakilan rakyat yang berkedudukan sebagai lembaga negara. Tiga fungsi utama Dewan Perwakilan Rakyat yaitu fungsi legislasi, fungsi anggaran, dan fungsi pengawasan. Ketiga fungsi tersebut mempunyai hubungan yang erat dan selalu bersentuhan dengan fungsi lainnya.

Salah satu fungsi pengawasan yaitu suatu kegiatan yang ditujukan untuk menjamin agar penyelenggaraan negara sesuai dengan rencana demi menjamin terlaksananya penyelenggaraan negara oleh lembaga-lambaga negara sesuai dengan hukum yang beralaku $^{7}$. Dalam menjalankan tugas-tugasnya Dewan Perwakilan Rakyat dapat menggunakan kewenangan yang dimiliki sebagaiman pada Pasal 20A ayat (1) UndangUndang Dasar Negara Republik Indonesia Tahun 1945 termaktub:

"Dewan Perwakilan Rakyat memiliki fungsi legislasi, fungsi anggaran, dan fungsi pengawasan"

Dalam menjalankan fungsi mengawasi jalannya pemerintahan dengan menggunakan hak maupun kewajibannya. Hak yang dimiliki oleh Dewan Perwakilan Rakyat adalah hak interpelasi, hak angket, dan hak menyatakan pendapat. Dalam merealisasikan fungsinya maka hak-hak Dewan Perwakilan Rakyat tersebut termasuk hak angket diletakan menjadi hak institusi atau hak kelembagaan. Pada dasarnya hak angket pernah diatur pada Pasal 70 Undang-Undang Dasar Sementara Republik Indonesia Nomor 7 Tahun 1950 (LN 1950-56, d.u. 15 Ag 1950) termaktub:

"Dewan Perwakilan Rakyat mempunyai hak untuk menyelidiki (enquete), menurut aturan yang ditetapkan dengan undang-undang”.

Pada awalnya mekanisme pelaksanaan hak angket mengacu pada Undang-Undang Republik Indonesia Nomor 6 Tahun 1954 tentang Penetapan Hak Angket Dewan Perwakilan Rakyat (Lembaran Negara Republik Indonesia Tahun 1954 Nomor 19; Tambahan Lembaran Negara Nomor 518). Pengertian dari hak angket menurut aturan yang ditetapkan dengan undang-undang yaitu hak untuk menyelidiki yang dimiliki oleh Dewan Perwakilan Rakyat. Kemudian hak untuk menyelidiki diatur kembali secara konprehensif pada ketentuan Undang-Undang Dasar Negara Republik Indonesia Tahun 1945 perubahan kedua yang disahkan pada tanggal 18 Agustus 2002 menjadi hak angket, sebagai salah satu upaya untuk menutupi kelemahan yang terdapat dalam Undang-Undang Dasar Negara Republik Indonesia Tahun 1945, dengan sebelum perubahan yang dirasakan dalam praktek ketatanengaraan selama ini banyak mengalami kekurangan. Sesuai dengan sistem ketatanegaraan yang mengalami pergeseran dari sistem ketatanegaraan sebelumnya

7 Sri Soemantri, Ketatanegaraan Indonesia Dalam Kehidupan Politik Indonesia, Jaya Abadi, Jakarta, 2005, hlm. 285. 
berdasarkan Undang-Undang Dasar Negara Republik Indonesia Tahun 1945 oleh karena itu, pemisahan kekuasaan eksekutif dengan legislatif itu makin tegas adanya ${ }^{8}$. Peran Dewan Perwakilan Rakyat semakin menonjol dengan adanya perubahan Undang-Undang Dasar Negara Republik Indonesia 1945, terlihat pada Pasal 20A Undang-Undang Dasar Negara Republik Indonesia Tahun 1945 yaitu:

1) Dewan Perwakilan Rakyat memiliki fungsi legislasi, fungsi anggaran, dan fungsi pengawasan.

2) Dalam melaksanakan fungsinya, selain hak yang diatur dalam pasal-pasal lain Undang-Undang Dasar ini, Dewan Perwakilan rakyat mempunyai hak interpelasi, hak angket, dan hak menyatakan pendapat.

3) Selain hak yang diatur dalam pasal-pasal lain Undang-Undang Dasar ini, setiap anggota Dewan Perwakilan Rakyat mempunyai hak mengajukan pertanyaan, menyampaikan usul dan pendapat, serta hak imunitas.

4) Ketentuan lebih lanjut tentang hak Dewan Perwakilan Rakyat dan angota Dewan Perwakilan Rakyat diatur dalam undang-undang.

Penggunaan peran Dewan Perwakilan Rakyat dalam berhadapan dengan pemerintah, dijelaskan secara tegas dalam konstitusional sehingga pergeseran kekuasaan yang nyata, baik dalam bidang legislasi maupun dalam bidang pengawasan politik berkaitan dengan kebijakan pemerintah ${ }^{9}$. Dengan demikian Dewan Perwakilan Rakyat sebagaimana yang telah dijelaskan tugas dan kewenangannya dalam Undang-Undang Dasar Negara Republik Indonesia Tahun 1945 dalam rangka membatasi kekuasaan pemerintah agar tidak bertindak secara sewenang-wenang, rakyat kemudian memilih perwakilannya untuk duduk dalam pemerintahan sebagai lembaga legislatif.

Hak angket Dewan Perwakilan Rakyat diatur dalam Pasal 20A ayat (2) UndangUndang Dasar Negara Republik Indonesia 1945 termaktub:

"Dalam melaksanakan fungsinya, selain hak yang diatur dalam UndangUndang Dasar ini, Dewan Perwakilan Rakyat mempunyai, hak interpelasi, hak angket, dan hak menyatakan pendapat."

Selanjutnya hak angket dipertegas kembali dalam Pasal 79 ayat (3) Undang-Undang Republik Indonesia Nomor 42 Tahun 2014 tentang perubahan atas Undang-Undang Republik Indonesia Nomor 17 Tahun 2014 tentang Majelis Permusyawaratan Rakyat, Dewan Perwakilan Rakyat, Dewan Perwakilan Daerah, Dan Dewan Perwakilan Rakyat

\footnotetext{
${ }^{8}$ Jimly Asshiddiqie, Hukum Tata Negara dan Pilar-Pilar Demokrasi, Sinar Grafika, Jakarta, 2012, hlm.16.

${ }^{9}$ Ibid, hlm. 63.
} 
Daerah (Lembaran Negara Republik Indonesia Tahun 2014 Nomor 383; Tambahan Lembaran Negara Nomor 5650) termaktub:

"Hak angket sebagaimana dimaksud pada ayat (1) huruf b adalah hak Dewan Perwakilan Rakyat untuk melakukan penyelidikan terhadap pelaksanaan suatu undang-undang dan/atau kebijakan Pemerintah yang berkaitan dengan hal penting, strategis, dan berdampak luas pada kehidupan bermasyarakat, berbangsa, dan bernegara yang diduga bertentangan dengan peraturan perundang-undangan."

Dalam demokrasi yang memberikan kebebasan pada rakyat untuk memilih orangorang yang membuat undang-undang, dimengerti bahwa partisipasi rakyat yang berdaulat terutama disalurkan melalui pemungutan suara rakyat untuk membentuk lembaga perwakilan. Mekanisme perwakilan ini dianggap dengan sendirinya efektif untuk maksud menjamin keterwakilan aspirasi atau kepentingan rakyat. Dewan Perwakilan Rakyat sendiri merupakan lembaga yang terdiri atas anggota partai politik peserta pemilihan umum dan terbentuk dalam beberapa fraksi yang merupakan pengelompokan anggota berdasarkan konfigurasi partai politik berdasarkan hasil pemilihan umum, berdasarkan Pasal 82 ayat (2) Undang-Undang Republik Indonesia Nomor 42 Tahun 2014 tentang perubahan atas Undang-Undang Republik Indonesia Nomor 17 Tahun 2014 tentang Majelis Permusyawaratan Rakyat, Dewan Perwakilan Rakyat, Dewan Perwakilan Daerah, Dan Dewan Perwakilan Rakyat Daerah (Lembaran Negara Republik Indonesia Tahun 2014 Nomor 383; Tambahan Lembaran Negara Nomor 5650), “setiap angota Dewan Perwakilan Rakyat harus menjadi angota fraksi”.

Pada dasarnya dinamika politik dalam sistem presidensial dan parlementer terdapat koalisi, namun dalam sistem presidensial sebagaimana dianut Negara Republik Indonesia memiliki dua makna yaitu pertama, koalisi sebagai sarana dalam menggalang dukungan partai politik atas pencalonan Presiden, ini terlihat dari Pasal 6A ayat (2) Undang-Undang Dasar Negara Republik Indonesia Tahun 1945 termaktub:

"Calon Presiden dan Wakil Presiden. Diusulkan oleh partai politik atau gabungan partai politik peserta pemilihan umum sebelum pelaksanaan pemilihan umum"

kedua untuk mengamankan stabilitas politik pemerintah terkait dengan kebijakan yang akan diambil oleh Presiden. Pemilihan Presiden tahun 2014 terdapat 2 (dua) peta kekuatan politik dilegislatif yaitu Koalisi Mera Putih yang terdiri dari Fraksi Partai Golongan Karya, Fraksi Partai Gerakan Indonesia Raya, Fraksi Partai Persatuan Pembangunan, Fraksi Partai Keadilan Sejahtera, dan Koalisi Indonesia Hebat terdiri dari Farkasi Partai Demokrasi Indonesia Perjuangan, Fraksi Nasional Demokrat, Fraksi Partai Kebangkitan Bangsa, 
Fraksi Partai Hati Nurani Rakyat dan Fraksi Partai Amanat Nasional. Pada aspek ini partai politik mempunyai posisi dan peran yang sangat penting dalam sistem demokrasi. Sehingga Dewan Perwakilan Rakyat dalam menjalankan wewenangnya terkait dengan hak angket yang menjadi hak istitusi melekat pada lembaga legislatif, dengan latar belakang dari partai maka tidak menuntut kemungkinan wewenang itu dinuansai oleh kepentingan partai. Mengingat partai memainkan peran penghubung yang sangat strategis antara proses-proses pemerintahan dengan warga negara. Bahkan banyak yang menyatakan bahwa partai politiklah yang menentukan demokrasi.

Berkaitan dengan penerapan hak angket dalam sistem tata negara Republik Indonesia yang dikenal setelah perubahan kedua Undang-Undang Dasar Negara Republik Indonesia Tahun 1945 tidak terlepas dari perkembangan kehidupan dan dinamika politik. Dalam mekanisme pelaksanaan hak angket terdapat dua acuan aturan hukum yaitu Pasal 1 ayat (1) Undang-Undang Republik Indonesia Nomor 6 Tahun 1954 tentang Penetapan Hak Angket Dewan Perwakilan Rakyat (Lembaran Negara Republik Indonesia Tahun 1954 Nomor 19; Tambahan Lembaran Negara Nomor 518) termaktub:

"Usul untuk mengadakan angket dimajukan dengan tertulis oleh sekurangkurangnya 10 orang angota Dewan Perwakilan Rakyat"

Dan Pasal 199 ayat (2) Undang-Undang Republik Indonesia Nomor 42 Tahun 2014 tentang perubahan atas Undang-Undang Republik Indonesia Nomor 17 Tahun 2014 tentang Majelis Permusyawaratan Rakyat, Dewan Perwakilan Rakyat, Dewan Perwakilan Daerah, Dan Dewan Perwakilan Rakyat Daerah (Lembaran Negara Republik Indonesia Tahun 2014 Nomor 383; Tambahan Lembaran Negara Nomor 5650) termaktub:

"Hak angket sebagaimana dimaksud dalam Pasal 79 ayat (1) huruf b diusulkan paling sedikit 25 (dua puluh lima) orang anggota Dewan Perwakilan Rakyat dan lebih dari 1 (satu) fraksi"

Berdasarkan Pasal 199 ayat (3) Undang-Undang Republik Indonesia Nomor 42 Tahun 2014 tentang perubahan atas Undang-Undang Republik Indonesia Nomor 17 Tahun 2014 tentang Majelis Permusyawaratan Rakyat, Dewan Perwakilan Rakyat, Dewan Perwakilan Daerah, Dan Dewan Perwakilan Rakyat Daerah (Lembaran Negara Republik Indonesia Tahun 2014 Nomor 383; Tambahan Lembaran Negara Nomor 5650) termaktub:

"Usul sebagaimana dimaksud pada ayat (1) menjadi hak angket Dewan Perwakilan Rakyat apa bila mendapat persetujuan dari rapat paripurna Dewan Perwakilan Rakyat yang dihadiri lebih dari 1/2 (satu per dua) jumlah anggota Dewan Perwakilan Rakyat dan keputusan diambil dengan persetujuan dari 1/2 (satu per dua) jumlah anggota Dewan Perwakilan Rakyat yang hadir" 
Terkait dengan penerapan hak angket, maka hak angket adalah suatu hak untuk melakukan penyelidikan atas kebijakan pemerintah dan pelaksanaan dari undang-undang yang berkaitan dengan hal penting, strategis, dan berdampak luas yang diduga bertentangan dengan peraturan perundang-undangan. Pengertian hak angket dalam Undang-Undang Republik Indonesia Nomor 42 Tahun 2014 tentang Majelis Permusyawaratan Rakyat, Dewan Perwakilan Rakyat, Dewan Perwakilan Daerah, Dan Dewan Perwakilan Rakyat Daerah (Lembaran Negara Republik Indonesia Tahun 2014 Nomor 383; Tambahan Lembaran Negara Nomor 5650). Tidak terdapat batasan pengertian yang begitu jelas terkait frasa "berdampak luas" merupakan satu frasa dengan mempunyai dua arti yakni mencakup pengertian politik dan hukum sekaligus.

Hak angket dapat digunakan sebagai dan atas nama rakyat untuk kepentingan golongan politik di legislatif dalam menentukan terkait kebijakan yang dikeluarkan oleh pemerintah untuk melakukan pencekalan dan/atau mengarah pada pemberian sanksi kepada pemerintah. Selama dukungan mayorotas di Dewan Perwakilan Rakyat menyetujui adanya penerapan hak angket.

\section{b. Implikasi Putusan MK Nomor: 36/PUU-XV/2017 Terhadap Pelaksanaan Hak Angket DPR Terhadap KPK}

Hak angket merupakan hak konstitusional DPR RI sebagaimana disampaikan dalam poin sebelumnya. Penyelenggaraan hak angket menurut DPR RI sebagai bentuk perwujudan dari prinsip hukum tata Negara yaitu check and balance. Konsep check and balance merupakan bagian dari hasil reformasi yang pada intinya ingin mewujudkan system perimbangan kekuasaan. Reformasi Mei 1998 memberikan banyak perubahan dalam ketatanegaran Indonesia, salah satu adalah ${ }^{10}$ kesadaran memperkuat proses check and balance antara cabang-cabang kekuasaan telah berkembang sedemikian rupa bahkan melampui konvensi yang selama ini dipegang yakni asas kekeluargaan di dalam penyelenggaraan Negara. Ketentuan ini bermasksud untuk menjadikan DPR RI berfungsi secara optimal sebagai lembaga perwakilan rakyat sekaligus memperkokoh pelaksanaan check and balance oleh DPR RI ${ }^{11}$.

Prinsip check and balance merupakan sarana kontroling antara cabang kekuasaan, sehingga konsekwensinya adalah ketiga cabang kekuasaan legislative, eksekutif, dan yudikatif memiliki derajat yang sama karena dapat saling megontrol satu sama lain.

\footnotetext{
${ }^{10}$ Ni'Matul Huda, Hukum Tata Negara Indonesia, 2014, rajawali pers, Jakarta, hlm 107

${ }^{11}$ Ibid. hlm. 112
} 
Berdasarkan prinsip check and balance ini, maka kekuasaan Negara dapat dibatasi sehingga peyalahgunaan kekuasaan dapat ditanggulangi dengan baik ${ }^{12}$. Pada prinsipnya pemisahan atau pembagian kekuasaan adalah untuk menghindari kekuasaan absolut atau sentralisasi kekuasaan sehingga kemugkinan penyalagunaan kekuasaan dapat terjadi.

Berkaitan dengan hak angket yang digulirkan kepada KPK sebagai wujud pengawasan DPR RI terhadap lembaga Negara sekaligus wujud prinsip check and balance. Namun pada dasarnya prinsip check and balance tidak dilakukan dengan melemahkan fungsi dan mengurangi independensi lembaga lain (KPK) yang justru akan mengganggu kinerja lembaga yang bersangkutan (KPK). Mengusulkan hak angket secara teoritis terdapat kekeliruan sebab sebagaimana alasan digulirkannya hak angket yakni meminta KPK membuka rekaman hasil pemeriksaan Miryam, dimana posisi KPK pada saat ini sebagai penegak hukum bukan sebagai pelaksanaan kebijakan maupun penentuan kebijakan. Menurut Jimly Asshiddiqie secara teoritis fungsi pengawasan oleh parlemen sebagai lembaga perwakilan rakyat dapat pula dibedakan, yaitu: ${ }^{13}$

a. Pengawasan terhadap penentuan kebijakan (control of policymaking);

b. Pengawasan terhadap pelaksanaan kebijakan (control of policy executing);

c. Pengawasan terhadap penganggaran dan belanja Negara (control of budgeting);

d. Pengawasan terhadap pelaksanaan anggaran dan belanja Negara (control of budget implementation);

e. Pengawasan terhadap kinerja pemerintahan (control of government performances);

f. Pengawasan terhadap pengangkatan pejabat publik (control of political appointment of publik officials) dalam bentuk persetujuan atau penolakan, atau dalam bentuk pemberian pertimbangan oleh DPR RI.

Berdasarkan pendapat di atas dapat diambil sebuah kesimpulan bahwa pengawasan DPR RI menggunakan hak angket terhadap KPK secara teoritis tidak terpenuhi atau salah sasaran mengingat DPR RI menggunakan hak konstitusionalnya (hak angket) hanya untuk meminta KPK membuka rekaman hasil pemeriksaan penyidikan terhadap Miryam. Sedangkan dalam posisi demikian pula KPK sedang melaksanakan kewangannya sebagai penegak hukum. Oleh karena demikian hak angket tidak dapat memberikan dampak signifikan terhadap KPK sebab permintaan DPR RI tersebut dapat saja ditolak KPK.

\footnotetext{
12 Ibid. hlm. 112.

${ }^{13}$ Jimly Asshiddiqie, Pengantar Ilmu hukum Tata Negara, Rajawali Pers, Jakarta, 2013.
} 
Selain secara teoritis, hak angket dapat dilihat melalui sudut pandang hukum positif Indonesia yaitu selain diatur UUD NRI Tahun 1945 juga diatur dalam UU MD3 yaitu Pasal 79. Mengenai metode pengesahan usulan hak angket diatur dalam Pasal 199 ayat (3) UU MD3 “usulan sebagaimana dimaksud pada ayat (1) menjadi hak angket DPR RI apabila mendapat persetujuan dari rapat paripurna DPR RI yang dihadir 1/2 jumlah anggota DPR RI dan keputusan diambil dengan persetujuan lebih dari $1 / 2$ jumlah anggota DPR RI yang hadir". Sedangkan untuk panitia angket dapat dilihat dalam Pasal 201 ayat (2) UUMD3 berbunyi "dalam hal DPR RI menerima usul hak angket sebagaimana dimaksud pada ayat (1), DPR RI membentuk panitia khusus yang dinamakan panitia angket yang keanggotaannya terdiri atas semua unsur fraksi DPR RI”.

Berdasarkan ketentuan yuridis di atas bahwa DPR RI menggunakan hak angket terhadap KPK berdasarkan penafsiran Pasal 79 ayat (3) yaitu DPR RI melakukan penyelidikan terhadap pelaksaan suatu UU. Hal ini dimaksudkan menurut DPR RI bahwa hak angket dapat ditujukan kepada KPK meskipun dalam posisinya sebagai penegak hukum yaitu melaksanakan UU dalam hal ini UU No. 30 tahun 2002 tentang Komisi Pemberantasan Korupsi (UU KPK) maupun UU No. 8 Tahun 1981 tentang Hukum Acara Pidana (KUHAP). Penafsiran demikian keliru meskipun unsur pelaksanaan suatu UU merupakan unsur tersendiri dan bersifat alternative atau komulatif, artinya diantara unsur Pasal 79 ayat (3) UU MD3 tersebut dapat memenuhi salah satu unsur saja atau seluruh unsur Pasal itu tetapi harus memperhatikan unsur yang terakhir yaitu hak DPR RI untuk melakukan penyelidikan terhadap pelaksanaan suatu UU diduga bertentangan dengan UU pula. Sedangkan proses penyidikan yang dialakukan KPK terhadap Miryam tidak terdapat adanya pelanggaran UU.

Selain itu, pelaksanaan Pasal 79 ayat (3) UU MD3 di atas harus memperhatikan ketentuan perundang-undangan yang lain, apakah dalam keadaan demikian (KPK sebagai penegak hukum) ketentuan UU tersebut harus dikesampingkan karena terdapat UU mengatur hal sama tetapi bersifat khusus. Alasan DPR RI menggunakan Hak angket kepada KPK ingin membuka rekaman hasil penyidikan terhadap Miryam, hal ini berkaitan dengan keterbukaan informasi publik karena DPR RI sebagai representative dari rakyat.

Ketentuan mengenai keterbukaan informasi publik dapat dilihat UU No.14 Tahun 2008 (UU KIP). Berdasarkan Pasal 17 huruf a UU KIP mengatur informasi yang dapat dikecualikan dimana informasi boleh tidak dibuka kepada publik (termasuk DPR RI) salah satunya apabila informasi itu dapat menghambat proses penyidikan suatu tindak pidana. 
Mengutif pendapat Abdulhamid Dipopramono bahwa ketentuan Pasal 17 huruf a UU KIP memberikan hak kepada penegak hukum, tidak hanya KPK, tetapi juga kejaksaan, kepolisian, untuk tidak mengungkap apapun kepada publik apabila dinilai informasi itu dapat menghambat proses penegakan hukum.

Abdulhamid juga berpendapat bahwa Pasal 17 huruf a UU KIP merupakan bentuk perlindungan Negara kepada penegak hukum dalam menjalankan tugasnya karena penegak hukum tidak boleh diintervensi. Ketentuan ini juga terdapat dalam Pasal 3 UU No.30 Tahun 2004 tetang KPK (UU KPK) yaitu "Komisi pemberantasan korupsi adalah lembaga Negara yang dalam melaksanakan tugas dan wewenangnya bersifat independen dan bebas dari pengaruh kekuasaan manapun”. Penjelasan Pasal ini menyebutkan "dalam ketentuan ini yang dimaksud dengan kekuasaan manapun adalah kekuatan yang dapat mempengaruhi tugas dan wewenang Komisi pemberantasan korupsi atau anggota Komisi secara individual dari pihak eksekutif, yudikatif, legislative, pihak-pihak lain yang terkait dengan perkara tindak pidana korupsi, atau keadaan dan situasi ataupun dengan alasan apapun”.

Berdasarkan ketentuan di atas, berkaitan juga dengan asas peraturan perundangundangan yaitu lex specialis derograt legi generalis (UU yang khusus mengesampingkan UU yang umum). Berkaitan dengan hal ini ketentuan UU MD3 yang mengatur hak angket terhadap lembaga Negara yang melaksanakan suatu UU (KPK) dapat dikesampingkan oleh UU KIP dan UU KPK yang bersifat khusus mengatur kewenagan KPK dan termasuk hasil penyidikan merupakan informasi yang dapat dirahasiakan oleh KPK karena apabila hasil penyidikan tersebut dibuka kepada publik (DPR RI) berpotensi menghambat proses penyidikan kasus mega korupsi e-KTP.

Mengenai sahnya pengusulan hak angket harus mendapatkan persetujuan $1 / 2$ dari anggota DPR RI yang hadir dalam sidang paripurna sebagaimana ditentukan dalam Pasal 199 ayat (3), sedangkan apabila melihat proses paripurna yang dipimpin oleh Fahri Hamzah tidak melalui pemungutan suara (voting). Sehingga dapat menimbulkan pertanyaan bahwa dari mana mengetahui lebih dari $1 / 2$ anggota DPR RI yang hadir dalam paripurna tersebut menyetujui usulan hak angket terhadap KPK sedangkan tidak dilakukan pemungutan suara. Selain itu panitia angket KPK terancam gagal karena terindikasi tidak memenuhi rumusan Pasal 201 ayat (2) UUMD3 karena panitia angket keanggotaannya terdiri dari semua unsur fraksi DPR RI sedangkan terdapat beberapa fraksi tidak akan mengirimkan anggotanya untuk bergabung dalam panitia angket KPK tersebut. 
Lebih lanjut, Hak angket KPK menurut Denny Indrayana yang ditulis dalam kolom opini harian kompas (5 Mei 2017) telah menabrak beberapa prinsip dasar lalu lintas bernegara yaitu pertama, sebagai badan lain yang berkaitan dengan kekuasaan kehakiman sebagaimana diatur dalam Pasal 24 UUD NRI Tahun 1945, KPK juga diproteksi dengan prinsip kemerdekaan kekuasaan kehakiman. Maka konsekwensinya adalah tugas dan kewenangan KPK terkait korupsi hanya dapat dinilai dan dikontrol melalui proses peradilan. Lembaga di luar yudikatif tidak berwenang bahkan dilarang untuk mengontrol kewenangan KPK dalam menangani kasus. Kedua, angket adalah hak penyelidikan DPR RI terhadap kebijakan pemerintah dalam hal ini eksekutif baik kementerian maupun nonkementerian. Sedangkan KPK merupakan Komisi Negara independen yang bukan bagian pemerintah sebagaimana diatur dalam Pasal 3 UU KPK. Sehingga menurut Denny Indrayana hak angket dapat dikategorikan sebagai bentuk intervensi DPR RI tehadap KPK dalam menangani kasus mega korupsi e-KTP yang seharusnya independen berdasarkan Pasal 3 UU KPK.

Lembaga ad interim (tujuan khusus) ini dibentuk berdasarkan UU No.30 Tahun 2002 tentang Komisi Pemberantasan Korupsi. UU tersebut mengatur pula tata cara KPK dalam menindak tindak pidana korupsi atau dengan kata lain sebagai lex specialis UU No.8 tahun 1981 (KUHAP) apabila terdapat konflik norma. UU KPK merupakan hukum pidana formil yaitu sebagai alat menegakkan hukum pidana korupsi (materil) sebagaimana diatur dalam UU No.31 Tahun 1999 Tentang Pemberantasan Tindak Pidana Korupsi dan UU No.20 Tahun 2001 Tentang Perubahan Atas UU No.31 Tahun 1999 Tentang Pemberantasan Tindak Pidana Korupsi.

Sebagaimana telah diuraikan sebelumnya bahwa KPK adalah lembaga negara independen dan bebas dari intervensi kekuasaan manapun, ketentuan ini dapat dilihat dalam Pasal 3 UU KPK. Kekuasaan yang dimaksud tidak terlepas dari 3 (tiga) cabang kekuasaan eksekutif, legislatif dan yudikatif dan bentuk kekuasaan lainnya yang berkaitan dengan tindak pidana korupsi (lihat penjelasan Pasal 3 UU KPK). Berdasarkan ketentuan tersebut berkaitan dengan hak angket DPR RI sebagai upaya meminta KPK membuka hasil pemeriksaan terhadap Miryam merupakan bentuk intervensi DPR RI dalam penegakan hukum pidana korupsi. Sebab Pasal 3 UU KPK maupun penjelasannya telah membatasi kekuasaan legislatif bahwa tidak bisa menggunakan upaya apapun termasuk hak angket dalam mengintervensi KPK dalam proses penegakan hukum pidana korupsi meskipun dengan dalih sebagai wujud pelaksanaan fungsi pengawasan. Pelaksanaan fungsi 
pengawasan DPR RI sebagaimana pendapat Jimly Asshiddiqie sebelumnya bahwa tidak dapat dilakukan terhadap KPK yang notabene sebagai lembaga independen dalam penegakan hukum pidana korupsi. Upaya pengawasan terhadap KPK sebagai penegak hukum hanya dapat dilakukan melalui proses peradilan.

Ditinjau dari pelanggaran terhadap UU pun hak angket tersebut tidak tepat sasaran karena alasan atau dasar penggunaan hak angket tersebut kurang sesuai sebagaimana diuraikan dalam poin sebelumnya. Sedangkan dalih hak angket yang lain adalah sebagai bentuk meminta pertanggungjawaban KPK sebagaimana diatur dalam Pasal 20 ayat (1) UU KPK. Ketentuan ini merupakan kewajiban KPK dalam menyampaikan laporannya kepada DPR RI, Presiden, dan BPK bersifat berkala bukan dalam sewaktu-waktu dan KPK dapat diminta pertanggungjawaban kinerjanya. Selain itu ketentuan tersebut berkaitan dengan asas akuntabilitas sebagaimana dalam Pasal 5 UU KPK. Pertanggungjawaban KPK untuk menyampaikan laporan kepada DPR RI merupakan laporan tahunan dan pertanggungjawaban tersebut tidak melalui hak angket tetapi itu merupakan kewajiban KPK seperti diatur dalam Pasal 15 UU KPK.

Selain ketentuan di atas, terdapat juga ketentuan lain yang dapat digunakan sebagai dasar argumen bahwa hak angket DPR RI salah sasaran yaitu Pasal 17 huruf a UU KIP. Sebagaimana diuraikan sebelumnya bahwa ketentuan ini sebagai pengecualian tidak dipublikasikannya informasi publik berkaitan dengan proses penyidikan karena berpotensi menghambat proses pengungkapan kasus mega korupsi e-KTP yang terindikasi banyak melibatkan "orang besar" negeri ini. Begitupun dengan dalih hak angket sebagai wujud prinsip check and balance dalam negara demokrasi. Pada dasarnya prinsip ini tidak dapat dibenarkan apabila dilakukan dengan melemahkan fungsi dalam menegakkan hukum pidana korupsi dan mengurangi independensi KPK sehingga mengganggu kinerja yang bersangkutan. Oleh sebab itu, pelaksanaan prinsip check and balance untuk mewujudkan keseimbangan antara cabang kekuasaan sebagai ciri khas demokrasi konstitusional yaitu dengan tidak mengganggu kemandirian dan melemahkan KPK.

Demi menjaga independensi KPK, secara yuridis telah diatur bahwa KPK dilarang mengadakan hubungan langsung atau tidak dengan tersangka atau pihak lain yang ada hubungannya dengan perkara tindak pidana korupsi yang ditangani KPK dengan alasan apapun seperti diatur dalam Pasal 36 UU KPK. Berdasarkan BAP yang dicabut Miryam bahwa terdapat keterlibatan anggota legislatif dalam kasus korupsi e-KTP oleh sebab itu hak angket DPR RI yang ditujukan kepada KPK secara teoritis maupun yuridis tidak tepat 
sasaran. Bahkan terindikasi DPR RI ingin mengintervensi, melemahkan dan menciderai kemandirian KPK dalam pengungkapan kasus korupsi e-KTP sehingga publik pun menentang tindakan wakil rakyat tersebut.

Tindak pidana korupsi sebagai extra ordinary crime sebagaimana diuraikan sebelumnya memberikan dampak terhadap kekuasaan pembentuk perundang-undangan untuk mengatur segala bentuk tindakan korupsi dan perbuatan yang mencoba menghalangi, mencegah, atau menggagalkan proses penegakan hukum pidana korupsi. Wujud komitmen pemerintah (dalam arti luas) dalam pencegahan dan pemberantasan korupsi di Indonesia dapat dilihat dalam ketentuan Pasal 21 UU No.31 tahun 1999 tentang Pemberantasan Tindak Pidana Korupsi, berbunyi "setiap orang yang dengan sengaja mencegah, merintangi, atau mengagalkan secara langsung atau tidak langsung penyidikan, penuntutan, dan pemeriksaan di sidang pengadilan terhadap tersangka dan terdakwa atau pun para saksi dalam perkara korupsi, dipidana dengan pidana penjara paling singkat 3 (tiga) tahun dan paling lama 12 (dua belas) tahun dan atau denda paling sedikit Rp.150.000.000 dan paling banyak Rp. 600.000.000”.

Berdasarkan ketentuan a quo terdapat beberapa unsur yang harus dipenuhi yaitu:
a. Setiap orang;
b. Dengan sengaja;
c. Mencegah, merintangi, atau menggagalkan;
d. Secara langsung atau tidak langsung penyidikan, penuntutan, dan pemeriksaan di sidang pengadilan; dan
e. Terhadap tersangka atau terdakwa atau pun para saksi dalam perkara korupsi.

Melihat substansi ketentuan ini bahwa tindak pidana tersebut (Pasal 21 UU Tipikor) merupakan bukan tindak pidana berdiri sendiri namun tindak pidana yang lahir atau berkaitan dengan tindak pidana korupsi. Artinya tindak pidana yang diatur dalam Pasal 21 UU Tipikor adalah tindak pidana turunan yaitu tindak pidana dapat terjadi apabila terdapat tindak pidana korupsi. Selain itu, tindak pidana Pasal 21 UU Tipikor bukanlah tindak pidana korupsi hanya saja berkaitan dengan tindak pidana korupsi. Letak keterkaitannya adalah adanya perbuatan yang mengganggu proses penegakan hukum pidana korupsi seperti unsur perbuatan melawan hukum yaitu perbuatan mencegah, merintangi, dan menggagalkan proses pemeriksaan di setiap tingkatan (penyidikan, penuntutan, dan pemeriksaan di persidangan). 
Berkaitan dengan hal tersebut, pemerhati korupsi Adami Chazawi berpendapat perbuatan mencegah adalah usaha agar tidak terjadi sesuatu seperti menghilangkan atau memusnahkan barang bukti atau menyuruh pelaku atau saksi melarikan diri ke luar negeri. Sedangkan perbuatan merintangi memerlukan syarat bahwa sesuatu itu telah terjadi, dan perbuatan menggagalkan adalah segala perbuatan dengan cara apapun yang menjadi penyebab gagalnya sesuatu. Tindak pidana dalam Pasal 21 UU Tipikor ini termasuk jenis tindak pidana formil. Mengenai tindak pidana formil Roni Wiyanto mengatakan14 delik formil adalah suatu perbuatan pidana yang sudah selesai dilakukan dan perbuatan itu mencocoki rumusan dalam Pasal UU yang bersangkutan. Pendapat demikian pada intinya, tindak pidana itu dianggap telah terjadi apabila telah selesai perbuatan yang dilarang itu dilakukan meskipun belum atau tidak terdapat suatu akibat.

Kaitannya dengan hak angket DPR RI kepada KPK memunculkan problem baru, yaitu setelah diteliti baik secara teoritis, yuridis, maupun legitimasi dari publik tidak terdapat pembenaran atas alasan penggunaan hak angket tersebut sebagaimana diuraikan sebelumnya. Oleh karena itu apabila hak angket tetap "dipaksakan" terindikasi adanya perbuatan untuk menghalangi proses penyidikan untuk membongkar kasus mega korupsi eKTP. Apabila dalam melanjutkan proses pembongkaran kasus korupsi e-KTP KPK merasa terganggu dalam bekerja maka anggota DPR RI dapat dijerat tindakan menghalangi proses penyidikan kasus korupsi e-KTP sebagaimana rumusan Pasal 21 UU Tipikor. Menerut Eddy Os Hiarej sebagaimana ditulis di kolom opini harian Kompas (8/5) yaitu jika KPK menganggap manuver politik DPR RI dengan menyetujui hak angket menghambat dan menghalangi kinerj KPK dalam mengungkap perkara korupsi e-KTP anggota DPR RI dapat dijerat dengan obstruction of justice atau tindakan menghalang-halangi proses penyidikan.

\section{PENUTUP}

\subsection{Simpulan}

Dari uraian diatas dapatlah dikemukakan bahwa beberapa kesimpulan antara lain sebagaui berikut:

1. Hak angket merupakan hak untuk mengetahui keadaan pemerintahan baik dalam rangka mengetahui pelaksanaan pemerintahan maupun untuk mencari bahan-bahan untuk merumuskan kebijakan, atau untuk memberikan persetujuan atau pertimbangan mengenai orang, keadaan atau suatu peristiwa. Hak angket bukan hak 
untuk mengetahui mengenai kemungkinan telah terjadi tindak pidana atas suatu kasus.

2. Ketidaktepatan konsepsi hak angket yang juga ditunjukkan dalam pelaksanaannya seperti DPR menyelidiki Bullogate, kasus BLBI dan lain-lain dapat (bahkan telah) mendistorsi fungsi DPR dalam pembentukan UU (legislasi) ataupun pengawasan terhadap pelaksanaan tugas pemerintahan dan pembelanjaan negara, termasuk pengangkatan pejabat publik dalam bentuk persetujuan atau penolakan, ataupun dalam bentuk pemberian pertimbangan oleh DPR. Oleh sebab itu, jika diharapkan fungsi tersebut terlaksana secara efektif, dinamis dan wajar maka perubahan UU MD3 harus dapat diinisiasi utamanya oleh anggota DPR sendiri. Harus ada keinginan kuat dari para anggota DPR untuk mereposisi diri sebagai wakil rakyat yang aspiratif dan mengabdi demi kepentingan seluruh rakyat yang diwakilinya. Keinginan yang kuat itu akan terjelma secara nyata, apabila mereka tidak di-reall, karena bersikap oposan dengan garis kebijakan partainya.

\subsection{Saran}

Memperhatikan hasil simpulan di atas, dapat dikemukakan beberapa saran sebagai berikut :

1. Legislatif atau DPR hendaknya agar membuat ketentuan tentang hak angket lebih jelas dan lugas, terutama tentang proses mekanisme penggunaan hak angket, sehingga tidak terjadi pelanggaran-pelanggaran dan pembiasan dalam proses penggunaan hak angket. Peneliti menyarankan agar hasil hak angket dapat menjadi dijadikan bukti di dalam ranah pengadilan, karena hasil penyelidikan dari hak angket tidak bisa dijadikan bukti dalam proses pengadilan. Hal ini menyebabkan terjadi pembiasan, tidak efektifnya peran DPR bahkan menyiakan anggaran dalam proses penyelidikan hak angket.

2. Perlunya sanksi tegas terhadap anggota DPR apabila dalam mengunakan hak angket menyalahgunakan, dan keluar dari asas-asas kepatuhan mekanisme hak angket. 


\section{DAFTAR PUSTAKA}

\section{A. BUKU}

Jimly Asshiddiqie, Hukum Tata Negara dan Pilar-Pilar Demokrasi, Sinar Grafika, Jakarta, 2012 , Menuju Negara Hukum Yang demokrasi, PT Bhuana Ilmu Populer, Jakarta, 2009 , Pengantar Ilmu hukum Tata Negara, Rajawali Pers, Jakarta, 2013

Ni’Matul Huda, Hukum Tata Negara Indonesia, Rajawali Pers, Jakarta, 2014

Soerjono Soekanto, Pengantar Penelitian Hukum-Cet Ke-3, Jakarta: UI Press, 1984

Sri Soemantri, Ketatanegaraan Indonesia Dalam Kehidupan Politik Indonesia, Jaya Abadi, Jakarta, 2005 , Tentang Lembaga-lembaga Negara Menurut UUD 1945, cet VII, PT Citra Aditya Bakti, 1993

\section{B. Peraturan Perundang-Undangan:}

- Undang-Undang Dasar Negara RI Tahun 1945

- Undang-Undang No. 17 Tahun 2014 yang telah diubah dengan UU No. 42 Tahun 2014 tentang MPR DPR DPD dan DPRD 